KAZIMIERZ W. KRUPA

Uniwersytet Rzeszowski

\title{
Sieci biznesowe i innowacyjność MSP
}

Sieci biznesowe to sojusze pomiędzy firmami, które wspólnie pracują nad realizacją zasadniczych celów gospodarczych (ryc. 1). Mogą one być ustalone między MSP w ramach klastrów, ale istnieją również poza klastrami. Sieci mogą być poziome i pionowe (zob. Štefko 2007):

- poziome są budowane między przedsiębiorstwami, które konkurują na tym samym rynku, są to m.in. grupy producentów „obsługujących” wspólnie sklepy detaliczne, np. w regionie N; - pionowe, dotyczą w szczególności rozwoju systemów dostawczych, sojuszy między przedsiębiorstwami należącymi do różnych poziomów realizacji zadań w tym samym łańcuchu wartości.

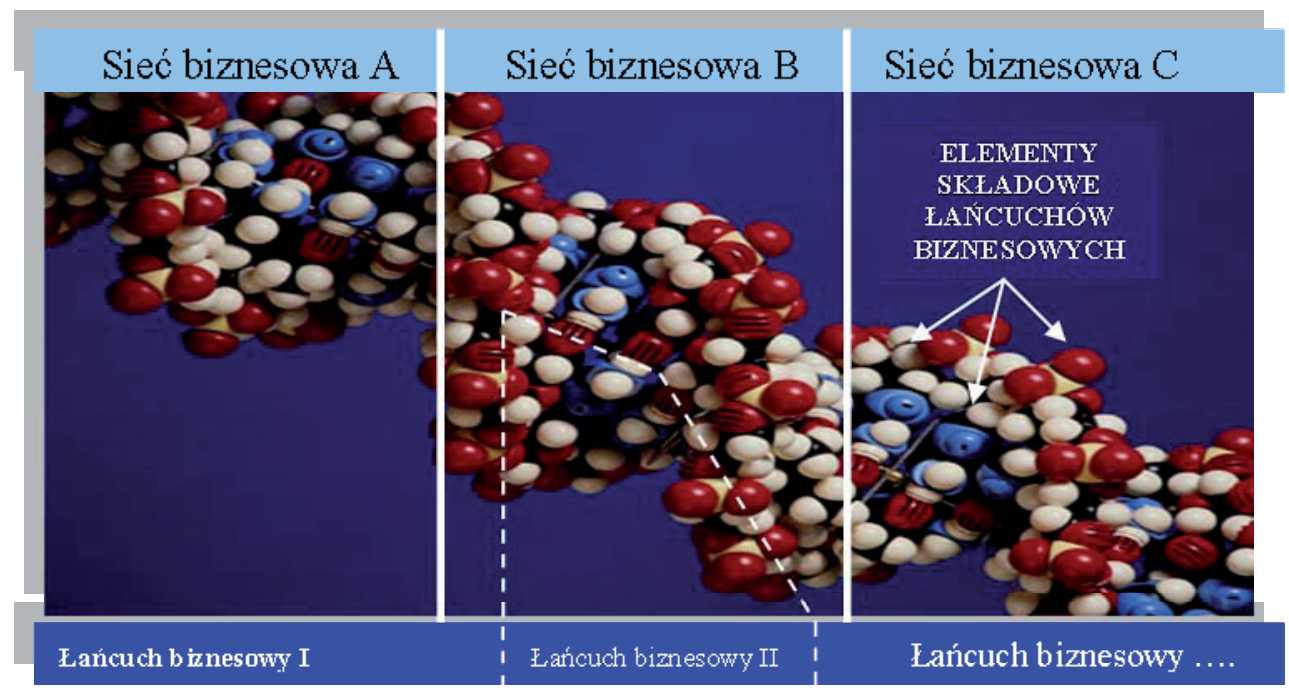

Ryc. 1. Sieci biznesowe

Źródło: opracowanie własne

Głównym celem budowania sieci, szczególnie technologicznej, jest ewolucyjna kooperacja pomiędzy firmami i innymi organizacjami koncentrującymi swą działalność bądź to na technologicznej modyfikacji, bądź na generalnych zmianach technologii. Działalność polega na tym, że aktorzy funkcjonują na różnych poziomach gospodarki, wykorzystują w realiza- 
cji swych funkcji technologię informatyczną i wytwarzają w ten sposób innowacje technologiczne potrzebne do rozwiązania specyficznych problemów. Jeśli problem zostanie rozwiązany, służąca do tego celu sieć często zanika, a rozpoczyna się budowanie nowej pracy w sieci technologicznej niezbędnej dla rozwiązania kolejnego odmiennego problemu biznesowego. Jednak w każdym takim przypadku wykorzystuje się istniejące doświadczenia, co przyspiesza budowanie nowych sieci. Jednym z przykładów takiego działania, szczególnie w strukturach Unii Europejskiej, są coraz liczniejsze narodowe bądź ponadnarodowe programy badawczo-rozwojowe, mające na celu opracowanie konkretnych technologii (biotechnologie, szczepionki, leki) wiążących w nowych strukturach potencjał innowacyjny wielu instytucji, organizacji i krajów. Przykładem może tu być również powstawanie licznych struktur wirtualnych. W powiązaniach tych można wyszczególnić wiele różnych poziomów działania podmiotów zorganizowanych połączonych w sieci poprzez decydujące dla innowacji więzi. Są to zazwyczaj powiązania:

- międzyinstytucjonalne i międzydyscyplinarne wewnątrz systemu prac B+R,

- między naukowcami a inżynierami, zwłaszcza w technologiach nazywanych bazowymi, jak biotechnologia, elektronika, nowe materiały,

- między aktualnymi i potencjalnymi użytkownikami nowych produktów i procesów technologicznych,

- powstające w różnych komórkach firmy, mające istotne znaczenie zarówno dla wytworzenia nowego produktu, jak i jego komercjalizacji, a więc pomiędzy komórkami projektowania, $\mathrm{B}+\mathrm{R}$, produkcji i marketingu,

- wyzwalające nową wiedzę i doświadczenie dla firmy i jej pracowników (wiedza własna i konkurencji) oraz korzystające z doświadczenia zewnętrznego (od dostawców, klientów, zleceniobiorców, doradców, uczelni, instytutów).

Zdaniem Š. Majtána (2008) sieci biznesowe i klastry stały się obecnie również słowami kluczowymi w debatach politycznych w krajach uprzemysłowionych i rozwijających się, głównie w UE (tab. 1). Są one traktowane jako narzędzia do zmniejszenia ubóstwa i promowania rozwoju konkurencyjnych MPS. Jednak kilka przeszkód może utrudniać im wykonywanie zdefiniowanej roli w strategiach biznesowych. Koncentrując się na szczególnych wyzwaniach stojących przed krajami rozwijającymi się, UNIDO sformułowała pięć kroków metodologii wspierania sieci biznesowych ${ }^{1}$ :

- wybór sieci, który pociąga za sobą ich identyfikację z perspektywy efektywnego wspierania całego współczesnego, szczególnie innowacyjnego łańcucha biznesowego;

- badania diagnostyczne, czyli działania zorientowane na analizę mocnych i słabych stron oraz szans i zagrożeń;

- wizja budowy i planowania działań - odnosi się ona do formułowania koncepcji ucieczki do przodu i tworzenia strategii rozwoju akceptowanych przez całą sieć lub klaster (analizowany projekt);

- wdrożenie, tj. zarządzanie i koordynacja działań określonych w operacyjnym planie realizacji, w tym szczególnie utworzenie sieci poziomych i pionowych;

- monitorowanie i ocena jakościowych i ilościowych rezultatów projektu.

Metodologia ta pozwala uruchomić proces rozwoju projektu budowy sieci biznesowej reagującej elastycznie na wyzwania globalnej gospodarki, szczególnie opartej na wiedzy. Aby proces ten uczynić trwałym w długim czasie, UNIDO zazwyczaj współpracuje z lokalnymi instytucjami wzmocnienia, budując jednocześnie ich zdolność do przyjęcia wiodącej

\footnotetext{
${ }^{1}$ Więcej zob. unido.org:podejście.
} 
roli w procesie wspierania przedsiębiorczości i innowacyjności nowych projektów biznesowych w przyszłych przedsięwzięciach.

Tab. 1. Klaster a sieć

\begin{tabular}{|l|l|l|}
\hline \multicolumn{1}{|c|}{ Kryterium } & \multicolumn{1}{|c|}{ Klastry } & \multicolumn{1}{|c|}{ Sieci } \\
\hline Członkostwo & $\begin{array}{l}\text { Otwarte - każdy podmiot może } \\
\text { przystąpić, lecz nie musi }\end{array}$ & $\begin{array}{l}\text { Przymusowe - charakter za- } \\
\text { mkniętego kręgu podmiotów }\end{array}$ \\
\hline Podstawa współpracy & $\begin{array}{l}\text { Ustalenia na bazie porozumień } \\
\text { społecznych - przyczyniające } \\
\text { się do zwiększenia zaufania }\end{array}$ & $\begin{array}{l}\text { Porozumienia oparte na długo- } \\
\text { terminowych kontraktach }\end{array}$ \\
\hline Korzyści & $\begin{array}{l}\text { Stworzenie odpowiednich } \\
\text { warunków rozwojowych dla } \\
\text { przedsiębiorstw o podobnym } \\
\text { profilu działalności }\end{array}$ & $\begin{array}{l}\text { Ułatwienie dla przedsiębiorstw, } \\
\text { szansa na uczestniczenie } \\
\text { w kompleksowym przedsię- } \\
\text { wzięciu biznesowym }\end{array}$ \\
\hline Wizja & Wizja wspólnego rozwoju & $\begin{array}{l}\text { Osiagnięcie korzyści głównie } \\
\text { o charakterze biznesowym }\end{array}$ \\
\hline $\begin{array}{l}\text { Relacje, związki pomiędzy } \\
\text { podmiotami }\end{array}$ & Współpraca oraz konkurowanie & W głównej mierze kooperacja \\
\hline $\begin{array}{l}\text { Przewaga nad innymi formami } \\
\text { współpracy }\end{array}$ & $\begin{array}{l}\text { Przyciaganie dużej liczby wy- } \\
\text { specjalizowanych podmiotów }\end{array}$ & $\begin{array}{l}\text { Oferowanie dostępu do wy- } \\
\text { kwalifikowanej siły roboczej } \\
\text { - niższy koszt }\end{array}$ \\
\hline $\begin{array}{l}\text { Podstawowe korzyści ze- } \\
\text { wnętrzne }\end{array}$ & $\begin{array}{l}\text { Czynnik lokalizacji, bliskość } \\
\text { współpracy }\end{array}$ & $\begin{array}{l}\text { Ścisła specjalizacja funkcji } \\
\text { oraz zasobów }\end{array}$ \\
\hline Bliskość geograficzna & Kluczowa & Mało istotna \\
\hline Wartość dodana & Wymierne korzyści zewnętrzne & $\begin{array}{l}\text { Koncentracja na kluczowych } \\
\text { kompetencjach }\end{array}$ \\
\hline
\end{tabular}

Źródło: Klastering i marketing terytorialny jako formy wzmocnienia polityki rozwoju regionów, 2008

Z myślą o małych i średnich przedsiębiorstwach innowacyjnych wykreowano dzięki polityce UE w jej strukturach sieć sieci czyli sub-sieć pod nazwą grup tematycznych. Są one usytuowane przy sieci Innovation Relay Centres ${ }^{2}$. Pierwsza Grupa Tematyczna specjalizuje się w zakresie komponentów do produkcji samochodów, technologii połowów morskich, materiałów, technologii medycznych i środowiska naturalnego

R. Štefko przekonuje, iż biorąc powyższe pod uwagę, można stwierdzić, że koncepcja pracy MPS w sieci wciąż się rozwija, ma jednak różny zakres w praktyce, mianowicie stanowi:

- powiązania między parkami technologicznymi a innymi rozmaitymi dziedzinami i obszarami,

- powiązania między parkami a lokalną gospodarką, w której one działają,

- technologiczną sieć powstającą bez konieczności łącznego spełnienia wszystkich wymienionych wcześniej specyficznych warunków, szczególnie majątkowych.

Rosnące zainteresowanie koncepcją pracy w sieci powoduje coraz szersze jej wykorzystywanie w łączeniu tradycyjnych form organizacyjno-kapitałowych w postaci konsorcjów,

${ }^{2}$ Transfers in Search of Intermediary: the Role of the IRCs, Innovation \& Technology Transfer, European Commission, July 1998. 
parków wirtualnych, mających charakter elastycznego i dostosowującego się „organizmu” jako nowego trendu w procesie tworzenia bądź zastosowania nowych technologii. Praca w sieci wymaga jednak wzbogacenia rozwiązań instytucjonalnych, zmiany zasad i metod zarządzania, a ponieważ przede wszystkim koncentruje się na ludziach, potrzebuje ludzi o nowych umiejętnościach.

Pomimo niepodlegających dyskusji korzyściach płynących z zastosowania sieci technologicznych, głównie wynikających z relatywnie niższych kosztów osiagania innowacji, wiele firm światowych coraz częściej preferuje jednak formułę gron przemysłowych, jak się wydaje, głównie ze względu na możliwość partycypowania w kosztach infrastruktury informacyjnej.

\section{Literatura}

Mačerinskien I., Š́bertová E., 2008, Present Role of Development Co-operative Society in Lithuania and in the Slovak Republic. Podnikanie a konkurencieschopnost' firiem. Bratislava.

Majtán Š., 2008, Manažérske rozhodovanie v outsourcingovom vzt'ahu. Podnikanie a konkurencieschopnost' firiem. Bratislava.

Rozwój gospodarki i zatrudnienia na szczebli lokalnym. Klastry gospodarcze: promocja przedsiębiorczości w Europie Środkowej i Wschodniej („Business clusters: promoting enterprise in Central and Eastern Europe") - http://www.oecd.org/dataoecd/7/4/35136926.pdf.

Shellock D., 2008, Europe and America offer Divergent Scenarios, „Financial Times”, May 16, p. 28.

Smith P., Dyer G., 2008, China ups Stakes in Iron ore Battle, "Financial Times", May 16, p. 14.

Scholtes S., Dyn von A., 2008, Will Consumer Credit Deal the Next Blow to Securities Trading? „Financial Times”, May 16, p. 27.

Sojka L., 2006, Regionálny rozvoj v kontexte vzdelanostných faktorov. Súbor záverečných štúdií vedeckého grantu VEGA č. 1/1406/04.

Sojka L., 2007, Kvalita pracovného života a súvisiace konštrukty.

Sojka L., 2003, Príspevok k tvorbe regionálnej stratégie, Štefko R. ed., Prešov.

Sojka L., 2005, Inovácie ako zdroj riešenia malého a stredného podnikania v zaostávajúcich regiónoch, [In:] Analytický pohl'ad na základné súvislosti z výzvy regionálneho rozvoja v slovenských podmienkach [elektronický zdroj]. Zbornik vedeckých štúdii z výskumného grantu VEGA c. 1/1406/04), Štefko R. ed., Prešov.

Sojka L., Kmecová A., 2005, Kompatibilita regionálnej stratégie a stratégii podnikatel'ských subjektov regiónu, [in:] Analytický pohl'ad na základné súvislosti z výzvy regionálneho rozvoja v slovenských podmienkach [elektronický zdroj]. Zbornik vedeckých štúdií z výskumného grantu VEGA c. 1/1406/04), Štefko R. ed., Prešov.

Soni V., 2008, An ode to Energy and Youth, ,Hindustan Times”, New Delhi, February 4, p. 30.

Stańczyk-Hugiet E., 2006, Zarzqdzanie wiedza w klastrach, [w:] Przedsiębiorczość i innowacyjność: wyzwania wspótczesności, Kaleta A., Moszkowicz K., Woźniak L. red., Prace Naukowe, nr 1116, Wyd. Akademii Ekonomicznej, Wrocław.

Štefko R., 2005, Analytický pohlad na základné súvislosti z výzvy regionálneho rozvoja v slovenských podmienkach. Zborník vedeckých štúdií z výskumného grantu VEGA č. 1/1406/04), Prešov.

Štefko R., ed., 2007, Znalostné determinanty regionálneho rozvoja : súbor vedeckých štúdií projektu VEGA č. 1/4638/07 a Centra excelentnosti výskumu kognicií, Prešov.

Štefko R., ed., 2007, Znalostné determinanty regionálneho rozvoja : súbor vedeckých štúdii projektu VEGA č. 1/4638/07 a Centra excelentnosti výskumu kognícií, Prešov.

Strategia Rozwoju Kraju 2007-2015, 2006, Ministerstwo Rozwoju Regionalnego, Warszawa, listopad.

Strategia Rozwoju Wielkopolskiego Klastra Meblarskiego, Kalupa Ł., Wielkopolska Agencja Rozwoju Przedsiębiorczości Sp. z o.o., Poznań 2007, http://www.klastermeblarski.warp.org.pl. 
Strategia rozwoju Zachodniopomorskiego Klastra Chemicznego, Koszarek M., Szultka S. przy współpracy Kapuścińskiego M., Instytut Badań nad Gospodarką Rynkową, Gdańsk 2006, http://www. rsi.org.pl/index.php/pl/Nowosci/1,70

Šúbertová E., 2008, Malé a stredné podniky a integrácia cooperatives Europe, Podnikanie a konkurencieschopnost' firiem, Bratislava.

Tsai K., Pekkanen S. ed., 2006, Japan and China in the World Economy (Politics in Asia Series) Routledge, London.

\section{Network business and innovation in SMBs}

Learn to do business in a funny way! Be part of an online community where interesting business ideas are turned into real business ventures. The online community is formed by aspiring entrepreneurs from all over the world. Entrepreneurs contribute business network ideas and the best ideas are voted to be implemented via the online community. The new economy deals with the economic interdependence among nations and SMBs. It analyzes the flow of goods, services, and payments between a nation and the rest of the world, the policies directed at regulating this flow, and their effect on the nation's welfare. This economic interdependence of innovations in SMBs is affected by, and in turn influences, the political, social, and cultural relations among small companies.

prof. UR dr hab. inż. Kazimierz W. Krupa

Uniwersytet Rzeszowski

Wydział Ekonomii

Katedra Ekonomiki i Zarządzania

e-mail: krupa@epf.pl 